\title{
Screening of Sweet Sorghum Accessions for Inhibition of Secondary Sporulation and Saccharide Measurements in Honeydew of Claviceps africana*
}

\author{
Amauri Bogo' 1 , Peter G. Mantle ${ }^{2}$ \& Oscar E. L. Harthmann ${ }^{3}$ \\ ${ }^{1}$ Departamento de Fitotecnia, Centro de Ciências Agroveterinárias - CAV/UDESC, Avenida Luiz de Camões, 2090, Cx. Postal \\ 281, CEP 88520-000, Lages, SC, e-mail: a2ab@cav.udesc.br; ${ }^{2}$ Biochemistry Department, Imperial College of Science, \\ Technology and Medicine, London SW7 2AZ; ${ }^{3}$ Escola Agrotécnica Federal de Rio do Sul, CEP 89160-000, SC, Brazil
}

(Aceito para publicação em 18/08/2003)

Autor para correspondência: Amauri Bogo

BOGO, A., MANTLE, P.G. \& HARTHMANN, O.E.L. Screening of sweet sorghum accessions for inhibition of secondary sporulation and saccharide measurements in honeydew of Claviceps africana. Fitopatologia Brasileira 29:086-090. 2004.

\begin{abstract}
Certain sweet sorghums (Sorghum bicolor) inhibit the secondary sporulation of Claviceps africana, which occurs on exuded ergot honeydew when the parasite is supplied with excess sucrose, which is then transformed to unique free oligosaccharides fructosyl - mannitol and difructosyl - mannitol with spore germination inhibiting properties. Five accessions (BRA-035726-SUGAR DRIP, BRA-035696-THEIS, BRA-036013-MN-4578, BRA-035947-MN-4418 and CMSXS-633) of sweet sorghum were selected among 50 evaluated. These five accessions

failed to support secondary sporulation on the "honeydew" exuded from infected florets. There was a higher concentration $(\% \mathrm{w} / \mathrm{v})$ of the free oligosaccharides on the honeydew of these accessions when compared to a hybrid male-sterile grain sorghum. Therefore, a possible strategy would be seek to incorporate a sweet character into "A" lines for hybrid seed production in order to restrict secondary disease spread. Additional keywords: Sorghum bicolor, germplasm bank, sugars.
\end{abstract}

\section{RESUMO}

Avaliação de genótipos de sorgo sacarino quanto à capacidade de inibir a esporulação secundária e avaliação da concentração de oligossacarídeos na secreção açucarada de Claviceps africana

Alguns genótipos de sorgo (Sorghum bicolor) sacarino inibem a esporulação secundária sobre a exudação de Claviceps africana. Estes genótipos fornecem ao parasita uma quantidade excessiva de sacarose, via floema, o qual é transformada em fructosil-manitol e difructosil-manitol que apresentam a propriedade de inibir a esporulação secundária do fungo. Dos 50 genótipos de sorgo sacarino avaliados, cinco (BRA-035726-SUGAR DRIP, BRA-035696-THEIS, BRA-036013-MN-4578, BRA-035947-MN-4418 e CMSXS-633) não apresentaram esporulação secundária sobre a secreção exudada dos floretes infectados. A quantidade de oligossacarídeos nestes cinco genótipos se apresentava em alta concentração $(\% \mathrm{w} / \mathrm{v})$ quando comparado com o híbrido macho-estéril de sorgo granífero. Portanto, uma estratégia de restringir a disseminação do patógeno, pela inibição da esporulação secundária, seria a incorporação da característica doce destes genótipos de sorgo sacarino nas linhas A de híbridos produtores de sementes.
The ergot pathogen of sorghum [Sorghum bicolor (L.) Moench], Claviceps africana Frederickson, Mantle and De Milliano (Frederickson et al., 1991) can cause significant economic losses in the production of $\mathrm{F}_{1}$ hybrid seed. Recent spread of the pathogen in the Americas (Reis et al., $1996 \mathrm{e}$ Bogo \& Boff, 1997) has focused attention on control measures. Sorghum is generally a self-fertile cereal, fertilization of each flower occurring within hours of the flowers opening and the enclosed anthers shedding pollen. In these circumstances spores of the ergot fungus $C$. africana, which behave like pollen on sorghum stigmas, but are slower to send a tube of tissue down to the ovule, often do not take over the ovary for parasitic purposes. Therefore, ergot disease is not usually a

*Parte da tese de Ph.D do primeiro autor. Imperial College of Science, Technology and Medicine, London, UK (2001). big problem in commercial grain sorghum production. However, the process of $F_{1}$ hybrid seed production requires the use of a male-sterile parent, which ultimately produces the $F_{1}$ hybrid seed, and a male progenitor, which is then discarded (Mantle \& Hassan, 1994). The low probability that the male parent will shed pollen exactly as the male-sterile flowers gape open, means that there will be a temporal gap of, perhaps several days between first receptivity of the female and the arrival of pollen on the stigma. Hence, ergot disease has a wide window of opportunity and therefore male-sterile sorghums are at high risk of infection by the relevant fungus (Bogo, 2001).

The consequences for sorghum are more severe than for any other cereal or grass host of the wide range of ergot pathogen world-wide, because the sorghum pathogen undergoes a unique process of secondary sporulation on the 
honeydew exudate, which arises from infected flowers about a week after infection. Secondary sporulation transforms spores, which are embedded in a liquid exudate into potentially airborne spores perched on a small fungal pegs above the liquid surface. This fungi is therefore windborne and has superior potential as a pathogen (Frederickson et al., 1989).

The reason that secondary sporulation occurs in $C$. africana honeydew is because of the low concentration of inhibitor sugar, which leaks from the diseased flower. The plant sap gives to the pathogen the disaccharide sucrose, which can not be used directly by $C$. africana, which brakes down the sucrose and uses the glucose component. Therefore, $C$. africana has biochemical mechanisms which incorporate unwanted fructose into oligosaccharides. The principal oligosaccharides in the honeydew are the di-(fructosylmannitol) and tri-saccharide (difructosyl-mannitol) containing one and two molecules of fructose and one of mannitol, respectively (Bogo, 2001). These oligosaccharides are inhibitors of secondary sporulation at a concentration of $1 \%$ in water (Hassan, 1996).

The present paper reports a strategy whereby, if a malesterile sorghum were to express a "sweet" character, as in sweet sorghums or sugar cane (Saccharum officinarum L.), both tropical sources of sucrose, so much sucrose would be leaked to the parasite that the excess over nutritional demand would be transformed by the fungus into the "toxic" oligofructoside, at a concentration that would generally be self-inhibitory for secondary sporulation in honeydew.

Experiments were conducted at "Escola Agrotécnica Federal de Rio do Sul, SC. The plot was $150 \mathrm{~km}$ from the Atlantic Ocean and at $650 \mathrm{~m}$ above sea level, where sorghum develops severe ergot infection in most years.

Seeds of 50 accessions of male-fertile sweet sorghums from the Germplasm bank of Embrapa Maize and Sorghum Research Center - CNPMS (Centro Nacional de Pesquisa de Milho e Sorgo), Sete Lagoas, MG,Brazil, were sown in an entirely randomizaded manner directly into the field soil (Inceptisols) in November 1999. The experiment constituted of two plots of $50 \mathrm{~m} \times 10 \mathrm{~m}$ containing all 50 accessions. Each accession was planted at $1.0 \mathrm{~m}$ intervals between $2.0 \mathrm{~m}$ rows (10 plants per row). In addition, a small plot of a male-sterile grain sorghum was available for comparative inoculation and inoculum production, approximately $500 \mathrm{~m}$ distant from the main plot.

Fresh inoculum of parasitically produced spores was made by shaking in water several freshly infected inflorescences bearing dried honeydew. These inflorescences had been produced in the male-sterile grain sorghum plot. The conidial suspension was filtered through a cotton cloth and diluted to contain approximately $1 \times 10^{6}$ conidia per milliliter. Inflorescences were tagged as first gaping florets appeared and inoculated with a hand sprayer until run-off. Inflorescences were subsequently inoculated daily until basipetal flushing of gaping was completed. Between five and seven days after inoculation, parasitic tissue could be observed as white rounded sphacelial mycelium, which protruded between floret glumes as they were forced wide apart. Between seven and ten days after inoculation, symptoms of honeydew production were visible. During the whole experimental period, inoculated panicles were scrutinized for honeydew exudation and the extent of macroscopic evidence of secondary conidiation by: (a) a 1-3 visual rating scale where $1=$ honeydew without whitening of the honeydew surface, $2=$ honeydew with some evidence of whitening of the honeydew surface $(>30 \%)$, and $3=$ honeydew coated with whitening on the surface $(<30 \%)$; and (b) the percentage of microscopic secondary sporulation determinde by counting the proportion of macrospores producing a sterigma or carrying a secondary spore in ten microscopic fields (x10 objective).

Since the sugars of $C$. africana honeydew are mainly fructosans, the quantification of total fructose after hydrolysis in the honeydew samples represented a combination of free fructose, the fructose in sucrose, and oligosaccharides. Fructose was quantified as a keto-sugar using Seliwanoff reaction (Bacon et al., 1948). The honeydew fructose quantification was made by reading the optical density of absorbance in four different dilutions with three replicates of each and related to a standard curve of fructose. The optical density of each solution was measured against the blank (reagents incubated with water) at $455 \mathrm{~nm}$ wavelength using a spectrophotometer (MSE Spectroplus). Standard fructose solutions $(10-90 \mu \mathrm{g} / \mathrm{ml})$, prepared in saturated benzoic acid and diluted with water, were treated similarly, and the linear calibration curve and analysis of variance (ANOVA) were used for statistical analysis. The concentration of each sample was expressed as $\% \mathrm{w} / \mathrm{v}$ using the fructose standard curve.

The oligosaccharides fructosyl-mannitol and difructosyl-mannitol were purified by descending Whatman No 3 MM paper chromatography using as solvent propan-1ol: ethyl acetate: water $(7: 1: 2)$. The oligosaccharides were located by dipping a strip of chromatograms in aniline hydrogen phthalate reagent and heating at $120^{\circ} \mathrm{C}$ for $20 \mathrm{~min}$.

Some of sorghum accessions started flowering in February 2000. Plant height was mainly between 2 and $4 \mathrm{~m}$ high and generally free from foliar diseases. Six accessions (BRA-035971-MN-4508, BRA-035980-MN-4509, BRA-035734WILLIANS, BRA-035921-MN-4080, CMSXS-630 and CMSXS-641) did not flower which implied particular photoperiod sensitivity for the six persistently vegetative accessions at this latitude (Table 1).

Of the 47 inoculated accessions, five (BRA-035726SUGAR DRIP, BRA-035696-THEIS, BRA-036013-MN-4578, BRA-035947-MN-4418 and CMSXS-633) never showed any signs of infection and exhibited a very high degree of seed set. Contrasting differences between pathogen biology on different germplasm accessions were observed among the other accessions at the end of the six week experimental period. In only one accession (BRA-035912-MN-4008) all panicles had infected florets. Also, some accessions had grown to an average height of at least $4 \mathrm{~m}$ while some had grown only half that height. Panicle habit was highly variable and ranged from 


\section{A. Bogo et al.}

TABLE 1 - Extent of secondary sporulation of Claviceps africana macrospores on honeydew exuded from infected sweet sorghums (Sorghum bicolor) genotypes

\begin{tabular}{|c|c|c|c|}
\hline Genotype & No. inoculated panicles & $\begin{array}{l}\text { No. of panicles with } \\
\text { symptoms }\end{array}$ & $\begin{array}{c}\text { Percentage of secondary } \\
\text { sporulation }\end{array}$ \\
\hline 1.BRA-035904-MN-4004 & 32 & 18 & 26 \\
\hline 2.BRA-035815-ROMA & 45 & 24 & 0 \\
\hline 3.BRA-035882-MN-1030 & 42 & 27 & 0 \\
\hline 4.BRA-035751-HODO & 22 & 11 & 72 \\
\hline 5.BRA-035653-BRANDES & 18 & 7 & 68 \\
\hline 6.BRA-035670-HOMEY & 21 & 6 & 57 \\
\hline 7.BRA-035858-MN-1060 & 12 & 9 & 83 \\
\hline 8.BRA-035955-MN-4423 & 15 & 12 & 42 \\
\hline 9.BRA-035718-WILEY & 27 & 8 & 61 \\
\hline 10.BRA-035793-RAMADA & 31 & 15 & 18 \\
\hline 11.BRA-035777-COLLIER & 17 & 7 & 26 \\
\hline 12.BRA-036005-MN-4514 & 9 & 3 & 55 \\
\hline 13.BRA-035840-MN-1056 & 25 & 13 & 14 \\
\hline 14.BRA-035700-TRACY & 22 & 5 & 23 \\
\hline 15.BRA035688-SART & 19 & 3 & 63 \\
\hline 16.BRA035785-REX & 10 & 4 & 27 \\
\hline 17.BRA035963-MN-4490 & 14 & 11 & 65 \\
\hline 18.BRA035971-MN-4508 & not flowered & 0 & not flowered \\
\hline 19.BRA035980-MN-4509 & not flowered & 0 & not flowered \\
\hline 20.BRA-035874-MN-752 & 42 & 13 & 0 \\
\hline 21.BRA-035734-WILLIANS & not flowered & 0 & not flowered \\
\hline 22.BRA-035823-MN-960 & 13 & 3 & 82 \\
\hline 23.BRA-035726-SUGAR DRIP & 15 & 0 & no symptoms \\
\hline 24.BRA-035696-THEIS & 8 & 0 & no symptoms \\
\hline 25.BRA-035661-DALE & 28 & 16 & 12 \\
\hline 26. BRA-036013-MN-4578 & 15 & 0 & no symptoms \\
\hline 27.BRA-035998-MN-4512 & 11 & 9 & 79 \\
\hline 28.BRA-035769-BRAWEY & 37 & 14 & 0 \\
\hline 29.BRA-035921-MN-4080 & not flowered & 0 & not flowered \\
\hline 30.BRA-035866-MN-1500 & not germinated & 0 & not germinated \\
\hline 31.BRA-035807-RIO & 16 & 2 & 47 \\
\hline 32.BRA-035939-MN-4291 & 12 & 5 & 73 \\
\hline 33.BRA-035891-MN-1996 & 23 & 7 & 20 \\
\hline 34.BRA-035912-MN-4008 & 7 & 7 & 68 \\
\hline 35.BRA-035947-MN-4418 & 9 & 0 & no symptoms \\
\hline 36. CMSXS-630 & not flowered & 0 & not flowered \\
\hline 37. CMSXS-607 & 18 & 4 & 48 \\
\hline 38. CMSXS-634 & 11 & 8 & 51 \\
\hline 39. CMSXS-632 & 9 & 5 & 67 \\
\hline 40. CMSXS-629 & 20 & 17 & 22 \\
\hline 41. CMSXS-631 & 5 & 2 & 80 \\
\hline 42. CMSXS-627 & 31 & 22 & 16 \\
\hline 43. CMSXS-633 & 25 & 0 & no symptoms \\
\hline 44. CMSXS-638 & not germinated & 0 & not germinated \\
\hline 45. CMSXS-641 & not flowered & 0 & not flowered \\
\hline 46. CMSXS-639 & not germinated & 0 & not germinated \\
\hline 47. CMSXS-642 & 34 & 10 & 27 \\
\hline 48. CMSXS-636 & 41 & 13 & 0 \\
\hline 49. CMSXS-637 & 9 & 2 & 21 \\
\hline 50. CMSXS-635 & 14 & 6 & 13 \\
\hline
\end{tabular}

$1=$ honeydew without whitening of the honeydew surface, $2=$ honeydew with some evidence of whitening of the honeydew surface $(>30 \%)$, and $3=$ honeydew coated of whitening of the honeydew surface $(<30 \%)$.

compact to very loose. However, five accessions (BRA-035815ROMA, BRA-035882-MN-1030, BRA-035874-MN-752, BRA035769-BRAWEY and CMSXS-636) showed no signs of secondary sporulation. In these accessions honeydew droplets were persistently viscous, golden brown and showed neither macroscopic signs of whitening on the honeydew surface nor microscopic signs of secondary sporulation. In some redpigmented sweet sorghum panicles the honeydew was also reddish-brown. Thirteen accessions showed honeydew with some secondary sporulation, but less than half of the spores 
Screening of sweet sorghum accessions for inhibition of secondary...

had germinated in a way that, macroscopically a faint whiteness on the honeydew surface could be observed, even though the honeydew was quite viscous. The remaining 18 accessions all displayed a high degree of secondary sporulation, over $30 \%$, the same as found in the male-sterile grain sorghums in the control plot $500 \mathrm{~m}$ away.

These differences in the degree that different accessions supported secondary sporulation in the same weather conditions allowed them to be classified as suppressive and non-suppressive sweet sorghum genotypes. The suppressive group comprised two types of sweet sorghum genotypes: Type I, comprised of five sweet sorghum lines, BRA-035815-ROMA, BRA-035882-MN-1030, BRA-035874-MN-752, BRA-035769BRAWEY and CMSXS-636 that showed no secondary sporulation under the most favorable conditions for secondary sporulation; and Type II, comprised of 13 sweet sorghum genotypes which had shown some secondary sporulation (< $30 \%$ ), though noticeably less than the group below, and which, therefore, may still have value as potential suppressors of secondary sporulation in the field. The non-suppressive group was comprised of 18 sweet sorghum genotypes which supported the maximum expression of secondary sporulation $(>30 \%)$, and on which the honeydew surface became coated with a white layer of secondary spores.

Oligosaccharides analysis (Table 2) of the honeydew exuded from the five accessions of sweet sorghums which did not support any secondary sporulation, showed high concentrations of fructosyl-mannitol and difructosyl-mannitol which were maintained even in humid conditions because the samples were all collected daily in the mornings before any sun-induced drying had occurred.

The average concentration of each of two fructosylalditols in each of the five sweet sorghum accessions was in the ratio of approximately 5:1 when compared to the male-sterile grain sorghum. The average percentage value of the total fructose after hydrolysis for sweet and grain sorghums was in the ratio of approximately 3:1 and of free fructose was approximately $2: 1$. These data imply that oligosaccharideproducing enzyme activity in the sphacelial tissue can readily utilize an increased supply of sucrose from the host and transform the excess efficiently to bioactive oligosaccharides. Morphological and physiological differences between the sweet and grain sorghum accessions were evident. Sweet sorghums have low grain productivity and are mainly used as forage for livestock. Cleistogamy is a desirable character in self-fertile sorghums to avoid infection, but, of course, it is irrelevant for breeding ergot-resistance male-sterile lines for disease escape during $\mathrm{F}_{1}$ hybrid seed production. Ergot disease resistance probably does not exist in sorghum except through floral biology.

Since unfertilized sorghum ovaries have not yet been found to have natural disease resistance to ergot, and since $C$. africana secondary sporulation in vivo seems to be a principal cause of epidemics, it has become increasingly important to control epidemics of the pathogen, especially in view of its recent global spread. Hence, an alternative strategy was the exploration of the sweet sorghum character for the control of the aerobiological dimension of $C$. africana epidemic development.

In the present study, most of the sweet sorghum accessions exhibited a lower degree of secondary sporulation when the environmental conditions were more humid than would be expected for grain sorghums. During dry conditions, the honeydew became sticky and highly viscous due to loss of water through evaporation. Consequently, the honeydew's fructosyl-alditols become even more concentrated to such an extent that conidial germination was suppressed even following a light rain shower. The data implies that the honeydew's fructosyl-alditols of the five asymptomatic accessions was still concentrated enough to be generally unaffected by high atmospheric humidity. Since honeydew is the partially exhausted phloem/xylem exudate in which excess sucrose has been transformed to these particular fructosylmannitol and difructosyl-mannitol sugars by sphacelial enzymes, the effective inhibitory factor in these five sweet sorghum honeydews could mainly be the concentration of these sugars.

The reason honeydew from infected grain sorghum is so dilute with respect to sugars is that the metabolic demands of the large sphacelium, which C. africana produces and which

TABLE 2 - Saccharide composition of combined Claviceps africana honeydew samples taken over several days from several inflorescences from one male-sterile grain sorghum (Sorghum bicolor) supporting secondary sporulation, and of samples from five sweet sorghums that did not support secondary sporulation. Saccharide values are expressed as \% $(w / v) \pm$ standard deviation $(n=4)$

\begin{tabular}{|c|c|c|c|c|}
\hline Sorghum line & $\begin{array}{c}\text { Total fructose after } \\
\text { hydrolysis }\end{array}$ & Free fructose* & $\begin{array}{c}\text { Fructose as } \\
\text { Fructosyl-mannitol* }\end{array}$ & $\begin{array}{c}\text { Fructose as } \\
\text { Difructosyl-mannitol* }\end{array}$ \\
\hline \multicolumn{5}{|l|}{ Sweet sorghum } \\
\hline BRA 035815 ROMA & $13.30 \pm 0.33$ & $0.636 \pm 0.01$ & $2.43 \pm 0.06$ & $6.33 \pm 0.03$ \\
\hline BRA $035882 \mathrm{MN} 1030$ & $15.09 \pm 0.14$ & $0.650 \pm 0.01$ & $3.36 \pm 0.08$ & $7.91 \pm 0.03$ \\
\hline BRA 035874 MN 752 & $16.38 \pm 0.59$ & $0.739 \pm 0.01$ & $3.28 \pm 0.13$ & $8.06 \pm 0.02$ \\
\hline BRA 035769 BRAWEY & $14.77 \pm 0.96$ & $0.611 \pm 0.01$ & $2.24 \pm 0.05$ & $6.72 \pm 0.09$ \\
\hline CMSXS 636 & $15.06 \pm 0.75$ & $0.524 \pm 0.01$ & $2.10 \pm 0.03$ & $7.75 \pm 0.07$ \\
\hline \multicolumn{5}{|l|}{ Grain sorghum } \\
\hline Male-sterile EMBRAPA-2114 & $5.13 \pm 0.44$ & $0.326 \pm 0.01$ & $0.64 \pm 0.03$ & $1.50 \pm 0.02$ \\
\hline
\end{tabular}

*Sugars analysed after separation by descending paper chromatography and obtained by Seliwanoff assay. 
has been consistently observed throughout the experiment, nearly exhaust the plant's phloem translocations. The vigor in producing a large parasitic sphacelium was notably evident in the sorghum infections seen in the recent South America epidemics particularly in Brazil.

An exploitable biochemical mechanism is therefore potentially available in these five sweet sorghums accessions (Table 1), and the use of a sweet character in the male-sterile A line in $F_{1}$ hybrid seed production seems to be a feasible strategy to suppress ergot epidemic development. However, breeding will be necessary to improve the habit of selected sweet sorghums so they are more suited to agronomical requirements for A lines. Selection from breeding material will need to maintain a highly functional expression of the sweetness character, that does not need to be maintained in the hybrid. This is more realistically monitored by exposure to the pathogen, but getting reliable results from the test is strongly influenced by the uncertainties of climate.

\section{ACKNOWLEDGEMENT}

We acknowledge EMBRAPA-CNPMS, Sete Lagoas. $\mathrm{MG}$, Brazil for germplasm bank seeds and the Escola Agrotécnica Federal de Rio do Sul, SC, Brazil for facilities to grow the accessions and research studentship support from CAPES, Brazil.

\section{LITERATURE CITED}

BACON, J.S.D. \& BELL, D.J. Glucose and fructose in the blood of the fetal sheep. Biochemical Journal 42:397-399. 1948.

BOGO, A. \& BOFF, P. Occurence of honeydew (Claviceps africana) on forrage sorghum in Brazil. Fitopatologia Brasileira 22:45. 1997.

BOGO, A. Biochemical physiopathology or some ergot fungi and other honeydew-producing plant parasites. Ph.D Thesis, Imperial College of Science, Technology and medicine, London, UK. 2001.

FREDERICKSON, D.E., MANTLE, P.G. \& DE MILLIANO, W.A.J. Secondary conidiation of Sphacelia sorghi on sorghum, a novel factor in the epidemiology of ergot disease. Mycological Research 93:497-502. 1989.

FREDERICKSON, D.E., MANTLE, P.G. \& DE MILLIANO, W.A.J. Claviceps africana nov. sp.; the distinctive ergot pathogen of sorghum in Africa. Mycological Research 95:1101-1107. 1991.

HASSAN, H.A.G. Control of ergot disease in sorghum with particular reference to Claviceps africana. Ph.D. Thesis, Imperial College of Science, Technology and Medicine, London, UK. 1996.

MANTLE, P.G. \& HASSAN, H.A.G. Widening geographical distribution of Claviceps africana, an important ovary pathogen of grain sorghum. International Sorghum and Millets Newsletter 45:9798. 1994.

REIS, E.M., MANTLE, P.G., \& HASSAN, H.A.G. Report in the America of Sorghum Ergot Disease, Caused by a Pathogen Diagnosed as C. africana. Plant Disease Reporter 80:463. 1996. (Note) 